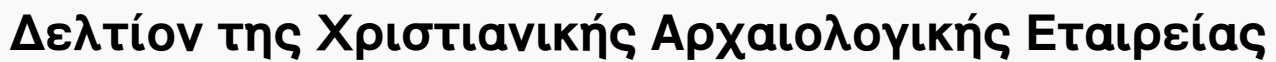

Tó 28 (2007)

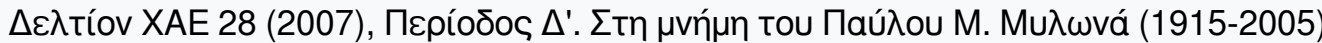

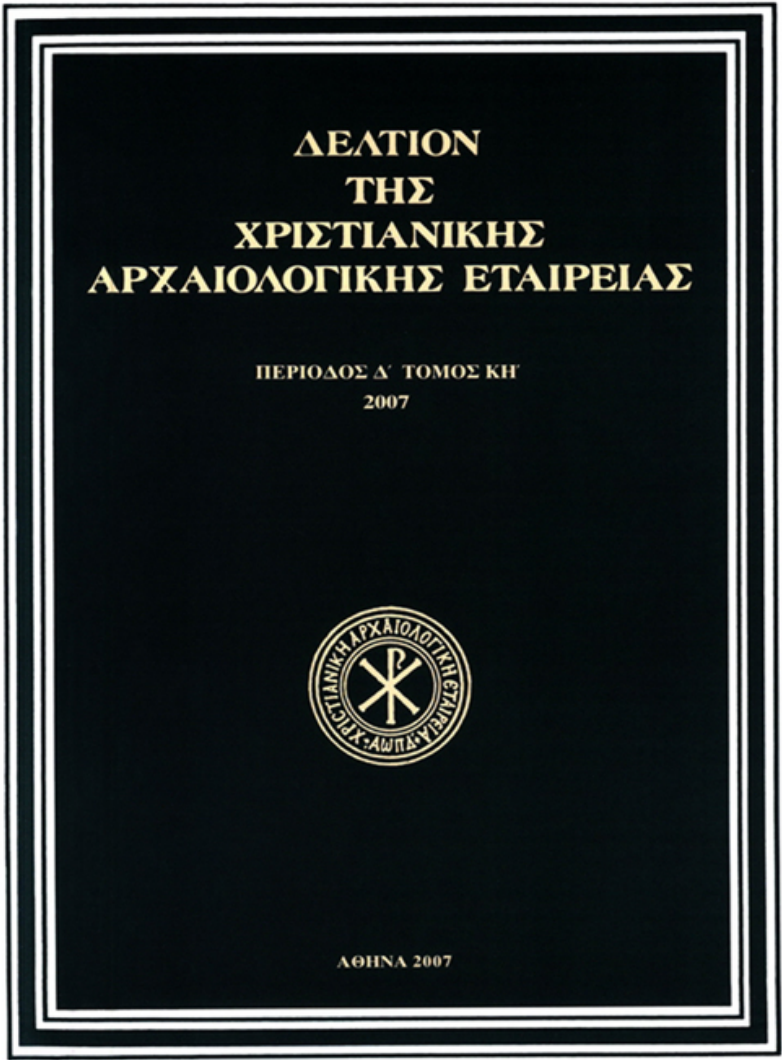

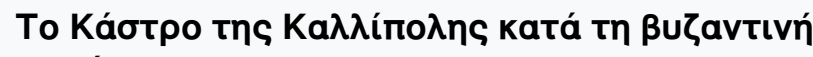
عாохń

Ayşe C. TURKER

doi: $10.12681 /$ dchae. 574

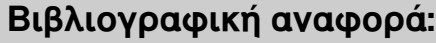

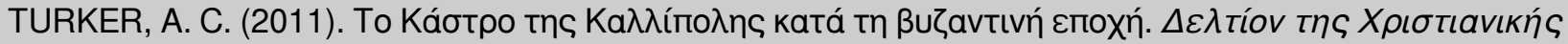

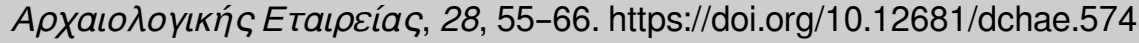




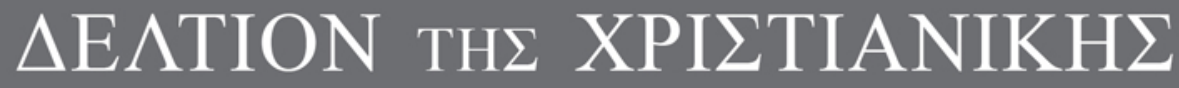 APXAIO $\Lambda$ ОГКН $\Sigma$ ETAIPEIA $\Sigma$}

The Gallipoli (Kallipolis) Castle in the Byzantine Period

Ayşe TURKER

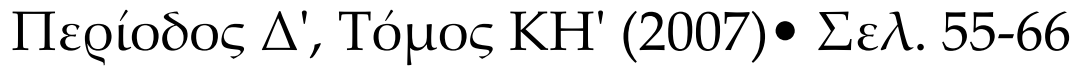
A@HNA 2007 


\section{THE GALLIPOLI (KALLIPOLIS) CASTLE IN THE BYZANTINE PERIOD}

\begin{abstract}
$\mathrm{T}_{\mathrm{h}}$ he Dardanelles Strait lies in the northeast-southwest direction between Gallipoli peninsula and Biga peninsula ${ }^{1}$. It has a $65 \mathrm{~km}$ seaway that connects the strait from Black SeaMarmara seas and Aegean-Mediterranean seas.

This position becomes prominent when considering the significance of the strait. The geography of the strait displays three different characteristics ${ }^{2}$. According to historical data, the strait, region had a strategic significance during the early Byzantine period. It is seen that Gallipoli, located at the up-
\end{abstract}

\footnotetext{
${ }^{1}$ In early cultures, Gallipoli peninsula is known as Thrace Kersonessos and Biga peninsula as Troas.

${ }^{2}$ The upper region begins in the area between Gallipoli and Cardak. It ends at a point close to cape and Karacaoren. This area is the northern mouth of the Strait and it is $3,200 \mathrm{~m}$. in width. Beginning from this point, the region between the Havuzlar in Gallipoli peninsula and Cape Kepez in Anatolian part is the central area. The width between Kilitbahir and Kocacay mouth is $1,200 \mathrm{~m}$. This point is the narrowest place of the Strait. The Strait gets wider beginning from this area. Beginning from central portion, the area between Cape Ilyas in the Gallipoli peninsula and Kumburnu at the Anatolian part constitutes the lower part of the Strait. This point constitutes the mouth of the Strait opening to the Aegean Sea. The width of the mouth is approximately $3,600 \mathrm{~m}$. The distance between this Aegean mouth and the Marmara mouth of the Strait is approximately $65 \mathrm{~km}$. There are many well protected natural ports extending from the upper mouth of the Gallipoli peninsula to the lower mouth of the Strait.

${ }^{3}$ Abydos-Sestos, Lapseki-Gallipoli, which are the cities facing one another settled or developed at points most feasible for crossing the Strait, are most strategic points of Hellespont. The positions of the settlements here enable control of the traffic on the seaway and also of major roads on the land. Historical data evidence the variation in importance of these strategic points in time and Sestos-Abydos passage was replaced by Gallipoli-Lapseki passage in twelfth century; see also A. Kazhdan, "Kallipolis", $O D B, 1094-5$; E. Eickhoff, Friedrich Barbarossa im Orient, Kreuzzug und Tod Friedrichs I, IstMitt, Beiheft 17, Tübingen 1977, 7882, Karte 1.

${ }^{4}$ The Crusaders of the Third Crusade chose to cross at Gallipoli as the initiation point of the east war. The German army coming from the Balkans under command of Friedrich did not attempt to cross Anatolia during winter time and Friedrich spent the winter season in Edirne. He
}

per part of the strait became strategically more significant particularly after the twelfth century ${ }^{3}$. According to historical records, Gallipoli continued to be a critical port for a long time owing to the fact that it shortened the passage from the European side to Anatolia on land. In addition, the focal point of the region always appears to have been Gallipoli Castle $^{4}$. We know of the existence of the Castle thanks to descriptive records, although it is not supported by archaeological material ${ }^{5}$. To contribute towards resolving this issue,

moved to Gallipoli in the Dardanelles Strait in March of 1190 and voyaged to Anatolia with Byzantine cargo ships. This information points out that Gallipoli used to have a significant position in crossing Anatolia from Europe and Balkans to reach to the East. See also S. Runciman, Hacli Seferleri Tarihi (transl. Fikret Işiltan), Ankara 1998, s. 12; Anna Komnena, Alexiad (transl. Bilge Umar), Istanbul 1996, s. 453; Heyd, Yakindoğu Ticaret Tarihi (transl. Enver Ziya Karal), Ankara, 2000, 312; D. M. Nicol, Bizans ve Venedik (transl. Gul Çagalı Guven), Istanbul 2000, 151; S Turan, Turkiye Italya Iliskileri, Ankara 2000, s. 203, 230-1; D. M. Nicol, Bizansın Son Yüzyılları 1261-1453 (transl. Bilge Umar), Istanbul 1999, 258; D. E. Pitcher, Osmanlı Imparatorlugu'nun Tarihsel Coğrafyası, (transl. Bahar Tirnakçi), Istanbul 1999, 67; G. T. Dennis, "1403 Tarihli Bizans-Turk Anlaşması" (transl. Melek Delilbaş), OCP XXXIII (1967), 72-88; Ankara Universitesi Dil Tarih ve Cografya Fakultesi Dergisi, XXIX, 1-4 (1979), 153. In the seventeenth century, Joseph de Tournefort describes Dardanelles Strait as a renowned strait and inwrites that this Strait is called the Gallipoli Strait, Aya Yorgi Strait, or Istanbul strait and that the Strait is called Mediterranean strait by Turks; see also J. Tournefort, Tournefort Seyahatnamesi II. Kitap (ed. Stefanos Yerasimos, transl. Teoman Tuncdogan), Istanbul 2005,9 . In addition, drawing attention to the tower, which is currently used as Piri Reis information centre, Tournefort informed that the tower planned as a square was built during the reign of Beyazid and that it was in ruins at that time See ibid. 10.

${ }^{5}$ For written and descriptive data on the tower, see also Evliya Çelebi Seyahatnamesi (ed. Y. Dağlı, S. A. Kahraman and İ. Sezgin), V. Kitap, Istanbul 2001, 162; S. Eyice, "Çanakkale Boğazı Kalelerinin XVI. Yüzyılda İtalya'da Basılmş Gravürleri”, Bedrettin Comert'e Armagan, Hacettepe Universitesi Sosyal ve Idari Bilimler Fakultesi Beseri Bilimler Dergisi Özel Sayı, Ankara 1980, 259-60, footnote 4; Mustafa Sevim (ed.) Gravürlerle Turkiye, Ankara 2002, 192, 193, 195-202, 206; Yeryüzü Suret- 


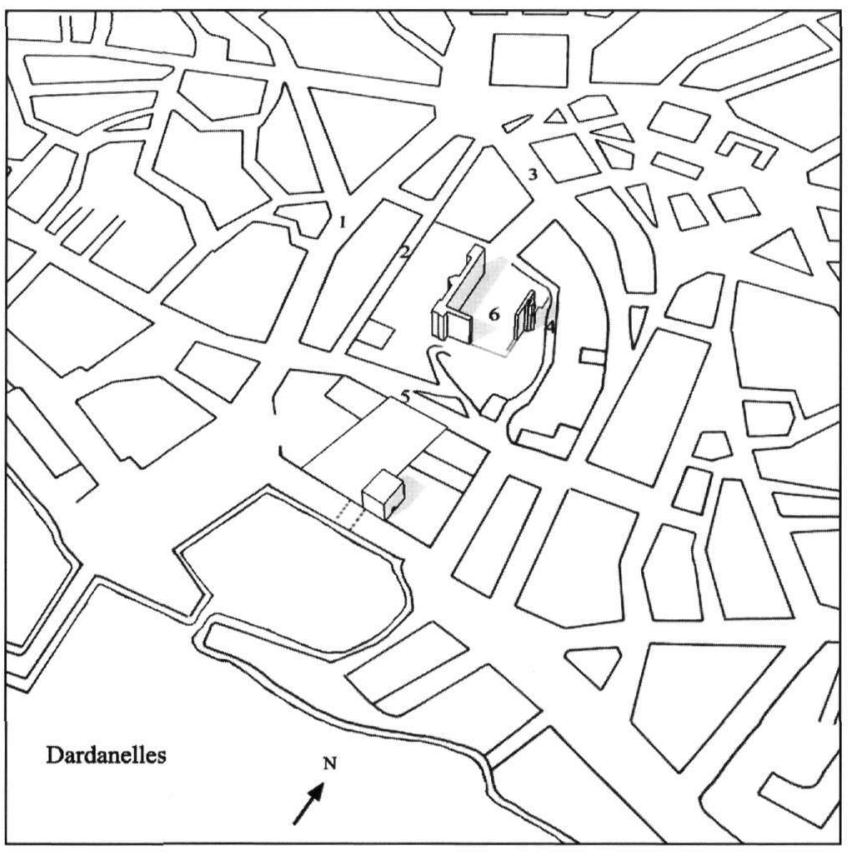

Fig. 1. Location of Gallipoli Castle (Drawing by Turker Turker) 1. Ibn Hasancik street, 2. Kale Bayiri street, 3. Yukarı Çarşı street, 4. Belediye street, 5. Sağlik merkezi street, 6. Kallipolis (Gallipoli) castle.

the walls and traces of walls in Gallipoli were examined ${ }^{6}$. Gallipoli developed on a headland surrounded by steep cliffs between Hamzakoy and Gallipoli bay situated at the northern mouth of the strait opening to the Marmara Sea ${ }^{7}$. Today, the traces of Gallipoli Castle may be observed on the hill reaching up to a height of $20-25 \mathrm{~m}$ from the inner port of the city which is sheltered from the harsh north winds that batter the city (Fig. 1). This hill reaches the inner port on a slope to the southwestern side. The east side of the hill is steep while the west side, where Gallipoli bay is located, is sloping. The shoulder of the hill gradually descends, starting from the inner port, to Kesan. Until 2002, the district Government Office -the governing centre of Gallipoli Countywas located at the head of this hill facing the inner port.

Just under the garden wall bordering the west side of the former district Government Office, there is a north-south wall, $6 \mathrm{~m}$ in height and $50.5 \mathrm{~m}$ in length (Fig. 2). The lower level of the wall is at the same ground floor level as the garden of the primary school, which is situated $12-14 \mathrm{~m}$ above the level of the inner port. The wall bordering the east side of the School's garden also serves as a retaining wall for the garden backfill of the government office. It is possible to say that the wall has preserved itself until today due to this function.

This wall, approximately $50.5 \mathrm{~m}$ in length, is named as the west defence line in our studies. The thickness of the wall, proceeding towards north-south direction, reaches $3 \mathrm{~m}^{8}$. To the north end of the wall, there is located a rectangular, or almost square, Tower I (Fig. 2). It is connected to Tower II with wall 'd'. Tower II has a pentagonal plan'; it is connected to Tower III by wall ' 1 ', which is situated at the south end of the wall and displays a corner tower plan. Differences are to be seen in the west wall, Towers I, II and III and the walls connected to the towers, all of which represent various building periods extending from the Byzantine Period to the twentieth century. leri Images of the Earth; Muhtar Katrrc1oglu Harita Koleksiyonu, Istanbul, Yapı Kredi Yayınları, 2001, 149, 169. In addition, there is an engraving of Gallipoli in the Seawright collection. I sincerely thank Dr. Filiz Işık who helped me gain access to this engraving. For further information on the collection, see also Filiz Ișı, Sultan Abdülmecit Donemi'nde (1839-1861) Osmanli Imparatorlugu'na Gelen Ingiliz Ressamlar: Victoria \& Albert Muzesi Seawright Koleksiyonu, Hacettepe Universitesi Sosyal Bilimler Enstitüsü, Yayimlanmamiş Doktora Tezi, Ankara 2004.

${ }^{6}$ During our studies called "Dardanelles Fountains" in 1995, the tower, serving as an information centre in Gallipoli, led us to think about where Gallipoli Castle might be. The Government Office to the north of the tower at a high point of town centrum was the primary and best estimation; therefore, we walked around the building. Before the fire in May 2002, we had noticed walls revealing Byzantine characteristics just under the surrounding wall at the west side facing Mustafa Kemal Primary Education School. Following the traces of the walls on the southern and eastern side of government office, we acquired a rough plan of the defence structure. When we worked on this wall and traces of the other walls in 1999, we had distinguished similarities and differences of the plan with engravings from the fifteenth and nineteenth centuries and we collected data that encouraged us to claim that such traces belonged to Gallipoli Castle.

${ }^{7}$ See M. Sakinç ve C. Yaltirak, "Guney Trakya Sahillerinin Denizel Pleyistosen Cokelleri ve Paleocoğrafyası", MTA Dergisi 119 (1997), 50 for the paleogeography of Gallipoli.

${ }^{8}$ The thickness given here was measured at sediment point where façade (c) and (d) wall of Tower I meets.

${ }^{9}$ The pentagonal towers were also detected in Ankara Tower, Dervish's Door and Perinthos in Trachea and Nessebar and Pliska in Bulgaria, see J. Crow ve A. Ricci, “The Anastasian Wall Project 1996-1997”, XVI. Araștirma Sonuçlari Toplantisi I. cilt, Ankara 1999, 239-49, esp. 239 and fig. 2. In addition İznik fortresses see C. Foss, "İznik'in Bizans Surları", Tarih Boyunca Ėnik, İstanbul, İș bankası yayınları, 2004, 249-62, esp. 257 fig. 13, and at Tocra, D. J. Smith ve J. Crow, "The Hellenistic and Byzantine Defences of Tocra (Taucheria)" Libyan Studies 29 (1998), 35-82, which show towers of similar types. 
In the first stage of our study, we aimed to find whether this wall, constituting west defence line of Gallipoli Castle, proceeds towards the south, east and north; therefore, we followed the topography in the east-west direction of the hill constituting the south line beginning from Tower III. We carried out these studies during the autumn and winter months when foliage was sparse. The wall technique created through the placement of 3 rows of stones inward in their half length at ground floor level of wall 'i' was also found in the first $5 \mathrm{~m}$ of wall ' $\mathrm{n}$ ' (Fig. 3). Such traces cease after $5 \mathrm{~m}$. The existing garden and terrace wall footing was been traced to this day and it was discovered that the traces of the south defence wall proceed for $25 \mathrm{~m}$ in the same direction (Fig. 3). The traces were not able to be followed after $25 \mathrm{~m}$ as topography to the east end of the hill changes. However, there is rubble including mortar approximately $55 \mathrm{~m}$ away in westeast direction from Tower $\mathrm{III}^{10}$. We have followed this mortar stone, northward and found that the mortar rubble proceeds $15 \mathrm{~m}$ in this direction. From this point, the mortar stone, having a maximum $2 \mathrm{~m}$ in thickness, proceeds $15 \mathrm{~m}$ in the same direction. It is difficult to conclude that these walls belong to the defence line of the castle. However, a tower we detected at this wall (Fig. 4) reveals that the mortar stone is associated with the defence line of the Castle. In almost the same direction, the size of the tower located in parallel to the pentagonal tower is nearly $3.5 \times 2 \times 0.40 \mathrm{~m}$ and the tower extends nearly $6.5 \mathrm{~m}$ towards Belediye Street. The height of the tower from this point to the garden level of the government office reaches $7.5-8 \mathrm{~m}$. According to the traces we followed, it can be said that the tower was pentagonal. Beginning from this castle, more mortar stone may be followed for $15 \mathrm{~m}$. At times the garden wall of the government office overlaps with these traces. It is seen that this mortar stone constitutes the footing of the garden wall (Fig. 4). From this point onwards, the wall traces headed towards Belediye Street; however, they could not be pursued any further. These data prove the existence of a defence wall of $50 \mathrm{~m}$ length lying in a north-south direction that covers the east side of the hill to the east side of the government office. The existence of a wall to the north side of the hill where the entrance to the government office is located cannot be con-

\footnotetext{
${ }^{10} \mathrm{G}$. Millet informs that Byzantines used mortar hardened with gravel, sand and large stone pieces in order to build strong walls. See G. Millet, L'école grecque dans l'architecture byzantine, Paris 1916, 214-51.

${ }^{11}$ Within the scope of my Project No 104K-074 titled "Dardanelles Strait and Settlement Models in the Byzantine Period" which is sup-
}

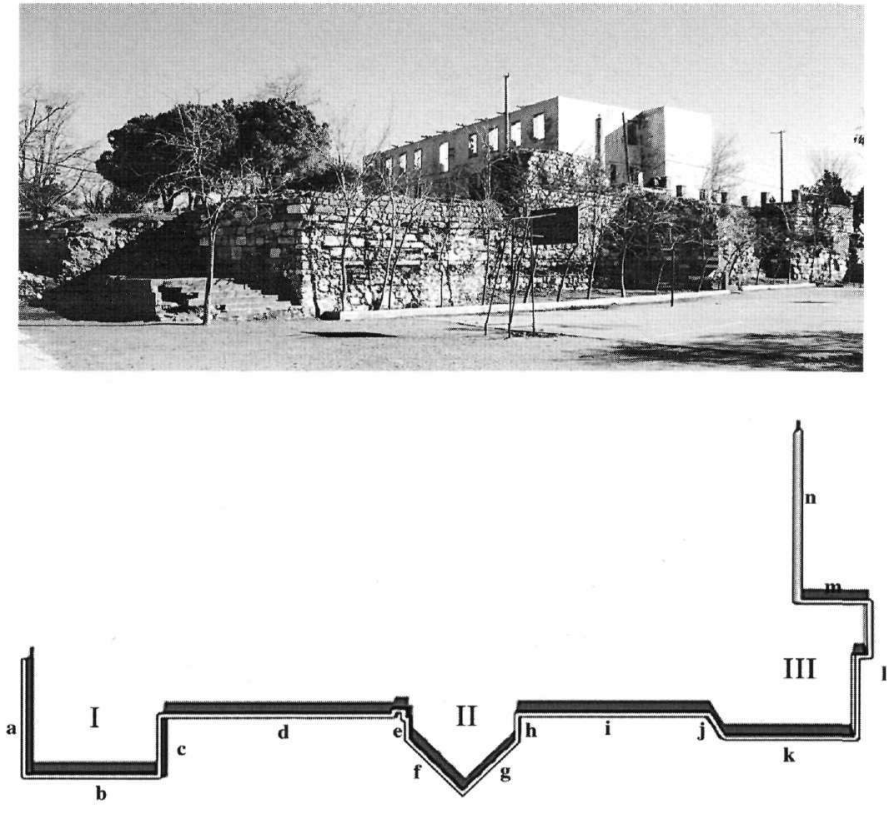

Fig. 2. $a$. The west defence line. $b$. The towers and sections in west defence line (Drawing by Turker Turker).

firmed through the following of superficial traces only. However, archeo-geophysical or excavation works to be performed at this point may provide significant information about the northern defence line. ${ }^{11}$.

From the data collected in the first stage, it may be understood that the defence wall covering the west, south and east directions of the hill has a square-like rectangular castle plan (Fig. 5). Even though the existence of the south wall of the castle facing the inner port is understood, there are inadequate supporting evidential traces.

In the second stage of our study, it was proposed that an evaluation be made of the defence line to the south. Also, we proposed to assess the descriptive evidence supporting the existence of the north wall of the castle.

In this respect, the engravings from the fifth and nineteenth centuries featuring Gallipoli Castle were evaluated. Using the method followed in the engravings, we attempted to arrive at an approximate plan of the castle retrospectively from

ported by TUBITAK, a part of the archaeo-geophysical studies to be performed in settlement regions we detected in Dardanelles Strait shall focus on understanding the northern and southern defence line of Gallipoli Castle. 


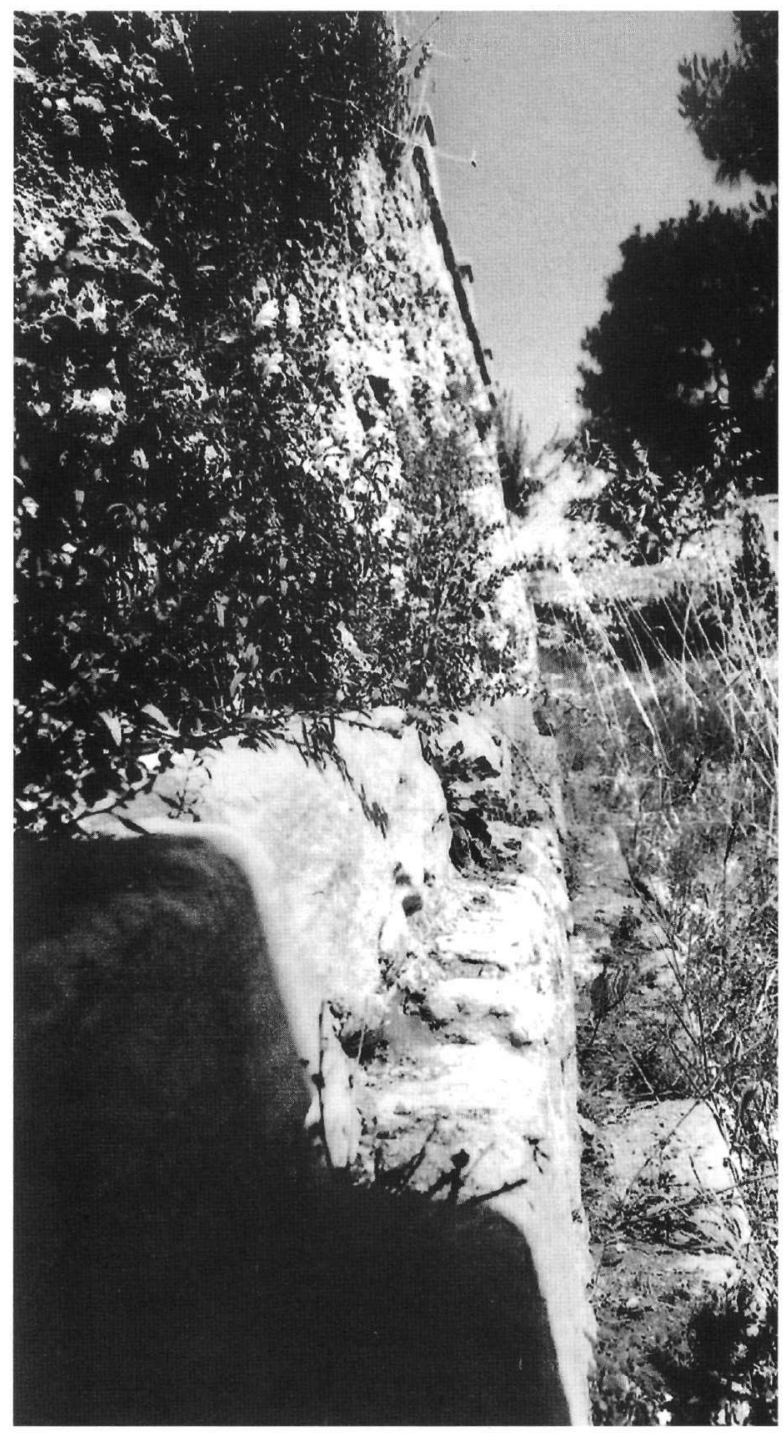

Fig. 3. The wall ' $n$ '.

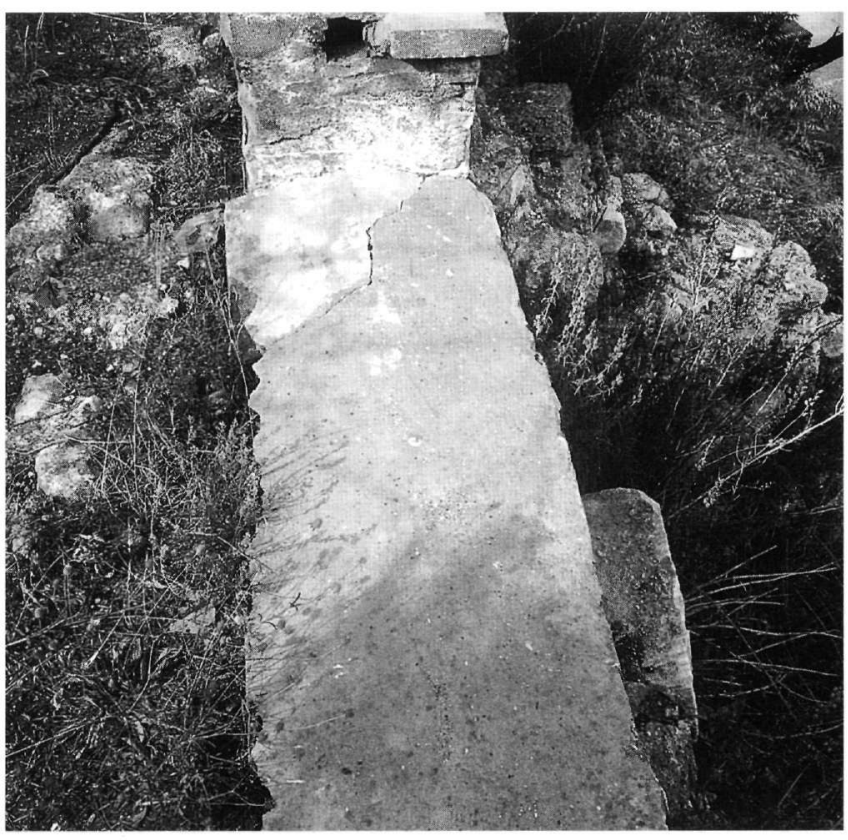

Fig. 4. The mortar stone under the contemporary garden wall.

the castle perspective ${ }^{12}$. The Gallipoli engraving of Christoforo Buondelmonti ${ }^{13}$ in London (Fig. 7) and Madrid dated $1410-1420$ is two of the earliest samples showing the castle. The engraving appears to reflect the topography of Gallipoli in a realistic manner. The plan we drew for Gallipoli Castle is similar to the Gallipoli Castle in the engraving of Buondelmonti in terms of the square-like rectangular plan of the Castle. Based on this information, the plan type of Gallipoli Castle may be dated back to the early Byzantine period. The engraving of Buondelmonti also includes a defence line to the north side of the Castle where we could not detect any entry point to northern side. However, Buondelmonti pic-

relevant semicircle; 5. The corner points of the Castle in the engraving were combined with the horizon line and connected to each other at $45^{\circ}$ angles; 6 . An approximate view of the Castle was thus obtained.

${ }^{13}$ Buondelmonti was a priest in Florence and lived on Rhodes to learn Greek. He visited Aegean islands and collected his observations in a book titled Liber Insularium Archipelagi. For further information about Buondelmonti see S. Eyice, Christoforo Buondelmonti, Istanbul 1964; G. Gerola, "Le Vedute di Constantinopoli di Christoforo Buondelmonti", RSBN 3 (1931), 249-65; C. Barsanti, "Un Panorama di Constantinopoli del 'Liber Insularum Archipelagi' di Christoforo Buondelmonti”, L'arte di Bisanzio e l'Italia al tempo dei Paleologi 1261-1453, Milion 5, Roma 1999. 
tured Gallipoli Castle with square shaped corner towers. Other towers were drawn almost circular in shape. These data contradict with the number and type of towers we have detected. Buondelmonti's Gallipoli description includes a natural harbour in front of the Castle. It is seen that the harbour is closed to the southwest direction with a wall descending to the sea from Tower III of the Castle. This wall apparently protects the natural harbour from the southwest winds. In addition, the engraving also pictures a rectangular tower which does not have any connection with the Castle. This tower lies, according to Gallipoli topography, in the area between the Fener and inner port. For this reason, it is not clear whether it is the same tower of Gallipoli Castle as the one in inner port. In the engraving, the topography where the tower is located appears to be piece of land extending towards the strait. Both sides of the tower are described as natural bays. Existence of a defence wall that closes both bays is traced behind the tower. According to these data, there was a second structure for defence purposes and it was independent of Gallipoli Castle.

The engravings dated 1854 and 1855 featuring Gallipoli Castle show a defence line to the south of the hill where there are three towers (Fig. 6). The approximate plans in Engravings $1^{14}$ and $2^{15}$ support the traces of the wall on the south side of the hill which we followed on the ground. The viewpoint of Engraving 2 is understood as being from the existing fish market towards the Castle. Especially in Engraving 2, it is seen that the Castle was an unusable ruin by the second half of the nineteenth century. It is understood that the third corner tower had a covering similar to a hipped roof. The roof of the tower, contradicting castle architecture, evidences that the Castle was used for purposes other than defence. The plans in Engravings 1 and $3^{16}$ provide data supporting the plan of the west defence line having three towers detected in Gallipoli Castle. The viewpoint of Engraving 1 is from the southwest and from the sea. Therefore, the existence of the walls in the west and south is traced. The engraving of J. Maurand ${ }^{17}$, engraved in the sixteenth century, shows three towers of the southern defence line. The viewpoint of Engraving 3 is from Gallipoli Avenue where

\footnotetext{
${ }^{14}$ This engraving was published by Jean Baptiste Henri Durand-Brager in 1855 in a book titled for the engraving see Mustafa Sevim, op.cit. (n. 5), 202.

${ }^{15}$ This engraving was published by E. De Granchamp in 1854 in a book titled for the engraving see Mustafa Sevim, op.cit. (n. 5), 206.

16 This engraving was published by E. De Granchamp, op.cit., ibid. For engraving, see Mustafa Sevim, op.cit. (n. 5), 205.
}

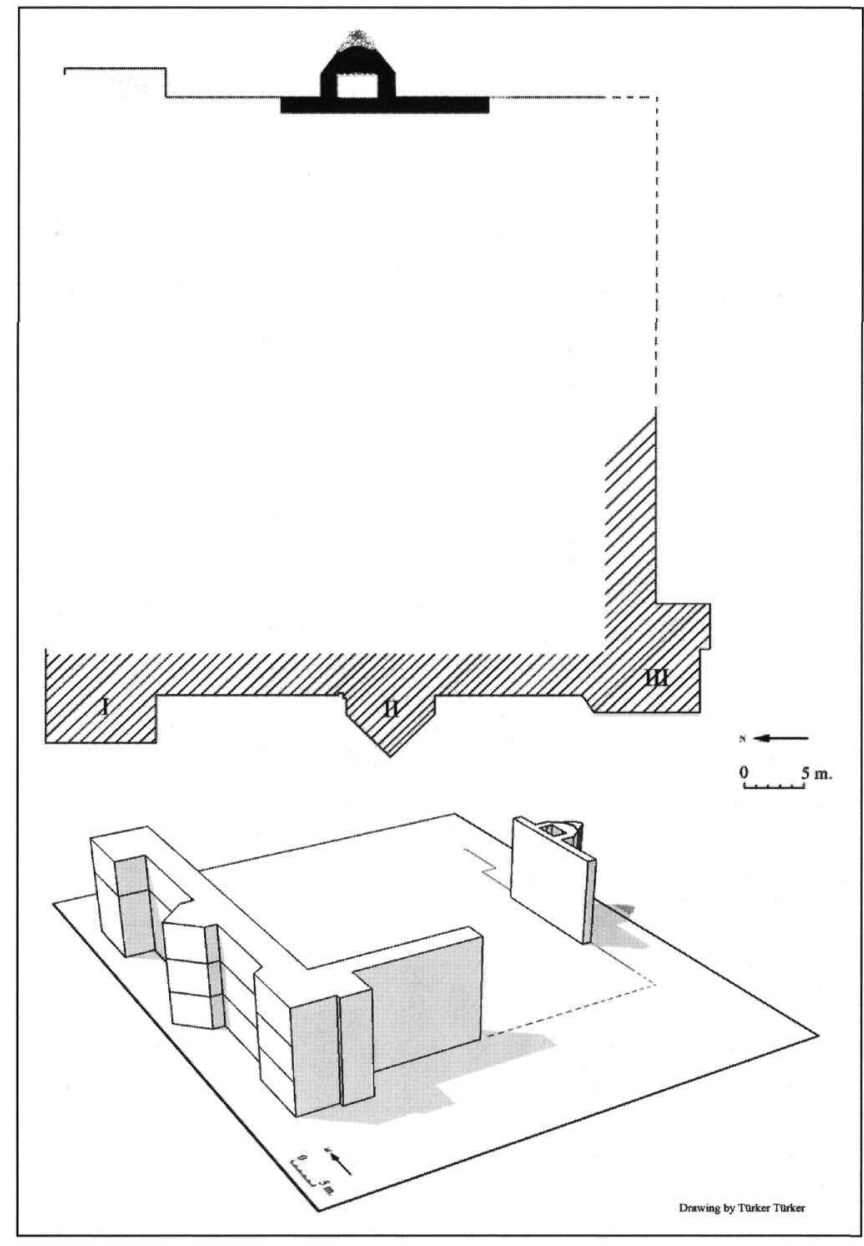

Fig. 5. Plan of Gallipoli Castle (Drawing by Turker Turker).

the statue of Mustafa Kemal Atatürk is located in the southwest direction. It shows the west wall of the Castle fortified by three towers. The plan of the west wall of the defence line cannot be seen in the engravings describing the Castle due to the fact that it is beyond the viewing angle of the artist of engraving.

The engraving in the travel book of Tournefor $\mathrm{t}^{18}$ displays Gallipoli from the south-western side and from the sea. The

\footnotetext{
${ }^{17}$ Eyice, op.cit. (n. 5), 260, fig. 4. The engraving belongs to J. Maurand; it was published in book titled Itinéraire d'Antibes á Constantinople (1544), prepared by L. Dorez.

${ }^{18}$ Eyice, op.cit. (n. 5), 260, fig. 5. The engraving was published in the book titled Relation d'un voyage du Levant fait par order du Roy... See Eyice, ibid., 260 for detailed information.
} 



Fig. 6. An approximate plan west and south wall from the castle perspective in engravings (Drawing by Turker Turker). a: Jean Baptiste Henri Durand-Brager; b: Granchamp; c: Granchamp.

defence line with three towers to the west side of the Castle is again pictured in this engraving. When evaluating the construction periods of wall 'd' located between Tower I and Tower II, as seen on the plan, it appears to reveal building traces dating earlier than the engravings of the fifteenth and nineteenth centuries.

In the third stage of our study, we aimed to assess the various building periods we traced at the west wall. Wall 'd' between 




Fig. 7. The Gallipoli engraving of Christoforo Buondelmonti.

Tower I and Tower II (Fig. 9) is approximately $15 \mathrm{~m}$ in length and its highest protected point is $6 \mathrm{~m}$ above ground floor level of the primary school's garden. The fact that some of the stones at the lower part of the wall were above ground and some were partially buried indicates that the wall continues and extends below the ground level of the primary school's garden. This could signify that the height of the wall might have increased. There are three to four courses of stone rising $60 \mathrm{~cm}$ above the lowest visible section of the wall. Above that level, there are six courses of brick that constitute the first band of bricks having a height of $45 \mathrm{~cm}$. Continuing with an alternating technique of construction, rising to a height of $1.80 \mathrm{~m}$ were nine courses of stone followed by a second band of bricks, then seven courses of stone were re- 




Phase 1

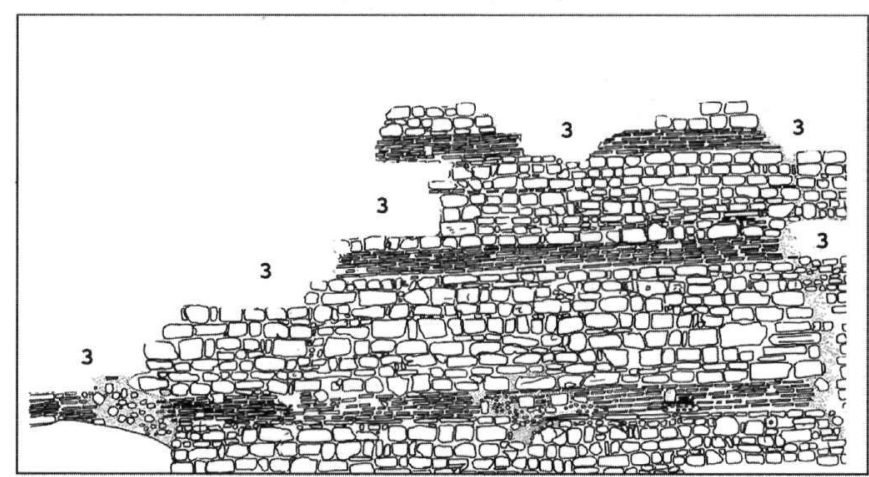

Phase 2

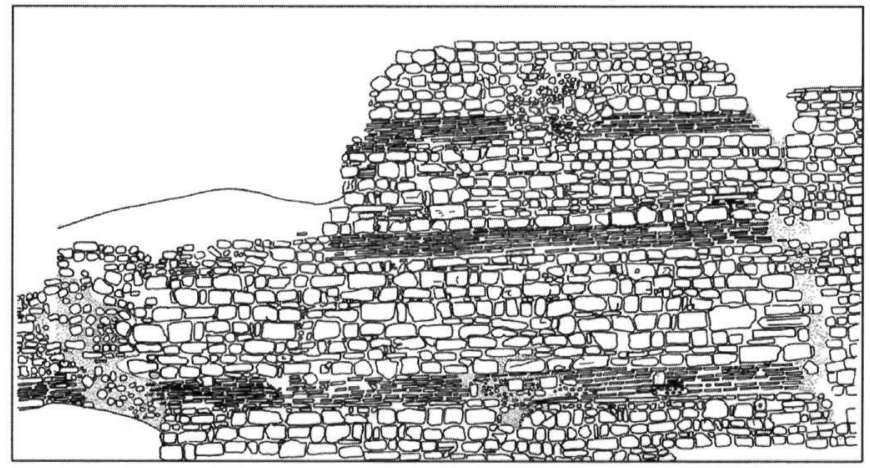

Phase 3

Fig. 8. The building periods in west defence line 'd' section (Drawing by Turker Turker).

19 See Z. Mercangoz, "Batı Anadolu'daki Turk Yapilarinin Duvar Teknigi ve Tugla Süslemelerinin Kaynağı Uzerine Duşunceler”, Dokuzuncu Milletlerarası Turk Sanatlari Kongresi, II, Ankara, Kultur Bakanliği, 1995, 485-95, esp. 485; for detailed information about alternating wall type used particularly during the Byzantine and early Otoman period see ibid., n. 1.

${ }^{20}$ For the castle walls in Istanbul during the early and middle Byzantine period, wooden connective girders were also used together with the bricks especially on narrow tower walls. However, no brick girders were used in city walls during Palaiologos, instead, narrow wooden girders were implemented in construction. See for information B. Meyer-Plath and A. M. peated rising a further $1.50 \mathrm{~m}$ after which a third band of bricks was similarly repeated ${ }^{19}$. A rectangular cavity sized $15 \times 22 \mathrm{~cm}$ is to be seen behind the first and third band of bricks parallel to the wall and extending throughout the wall. There are ten additional cavities having dimensions of $23 \times 22 \mathrm{~cm}$ repeated at every $1 \mathrm{~m}$ interval along the wall perpendicular to the upper edge of the top of the $15 \mathrm{~cm}$ horizontal cavity. These cavities are to be observed within the mortar stones. It is thought that these are cavities were created due to the decaying of wood within the mortar ${ }^{20}$, and is authenticated by the presence of a preserved piece of wood found in the second cavity perpendicular to the wall behind the third band of bricks ${ }^{21}$.

The sizes of the bricks at wall ' $d$ ' are $36-37 \times 20 \times 4 ; 38 \times 5$; $37 \times 4.5 \mathrm{~cm}^{22}$. The height of the seam joint between the bricks is $4 \mathrm{~cm}$. The same sized bricks were used in all three bands of brick at wall ' $d$ '. These materials show no variation until the first band of bricks at the lowest stone level of wall ' $c$ ' in Tower I of west wall. The material and technique ending at the corner of wall ' $c$ ' cannot be traced at the northern side of the wall. However, the same material and technique are used at Tower II and Tower III that are located at the southern side of the west wall. The material and technique employed at the first and second brick courses of wall ' $\mathrm{d}$ ' does not change at the first and second brick courses of walls 'e' and ' $\mathrm{f}$ ' (Fig. 10). On the other hand, the brick courses end at the corner where walls 'e' and 'd' of Tower II meet (Fig. 10). According to these data, the corner connecting the pentagonal tower to wall ' $d$ ' appears to represent a different building period. The first band of bricks comprising the six courses of brick at wall ' $\mathrm{g}$ ' of the pentagonal tower had crumbled; however, the horizontal stones forming the base of the bricks and traces of mortared bricks indicate that the band continues up to that point. The materials and technique of walls ' $d$ ', 'e' and ' $\mathrm{f}$ ' repeat in the second band of bricks of the same wall. The bricks at the level of the first band of bricks had crumbled at wall ' $\mathrm{g}$ ' of the pentagonal

Schneider, Die Landmauer von Konstantinopel, II, Berlin 1943, $22-6$.

${ }^{21}$ These wooden cavities are traced through damage to the wall in 2000. During our studies on this wall, we observed that the cavities in the walls were deliberately enlarged through breaking and the width of the cavity had increased especially after burning of the Government Office. The wooden structure observed in the second cavity, which is perpendicular to the wall located behind the third band of bricks constitutes significant chronological data in archaeometric assessment of the structure. This data will be assessed in the TUBITAK project that we have undertaken.

${ }^{22}$ For sizes of bricks in Byzantine structures see M. İ. Tunay, Türkiye'de Bizans Mimarisinde Taș ve Tuğla Tekniğine Gore Tarihlendirme, Istanbul 


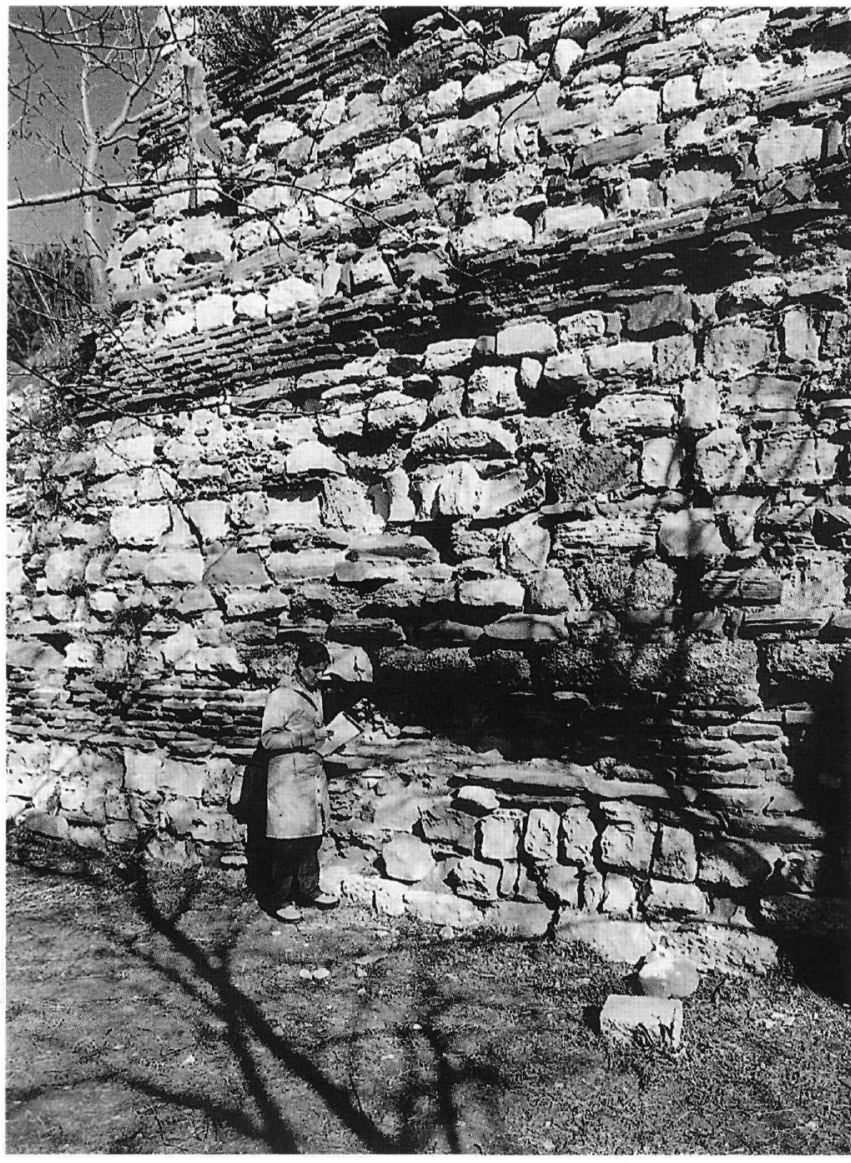

Fig. 9. The 'd' section in west defence line.

tower, while the courses of brick to the south of wall ' $h$ ' still remain today. However, the section at the level of the second band of bricks is filled with the stones used in wall ' $i$ '. Wall 'i' does not display the alternating wall technique filled with bricks and stones, and the wall was renovated to a large extent. It can, however, be seen that the cavities for girders seen in wall ' $d$ ' are also observable in this wall. Leaking rain-

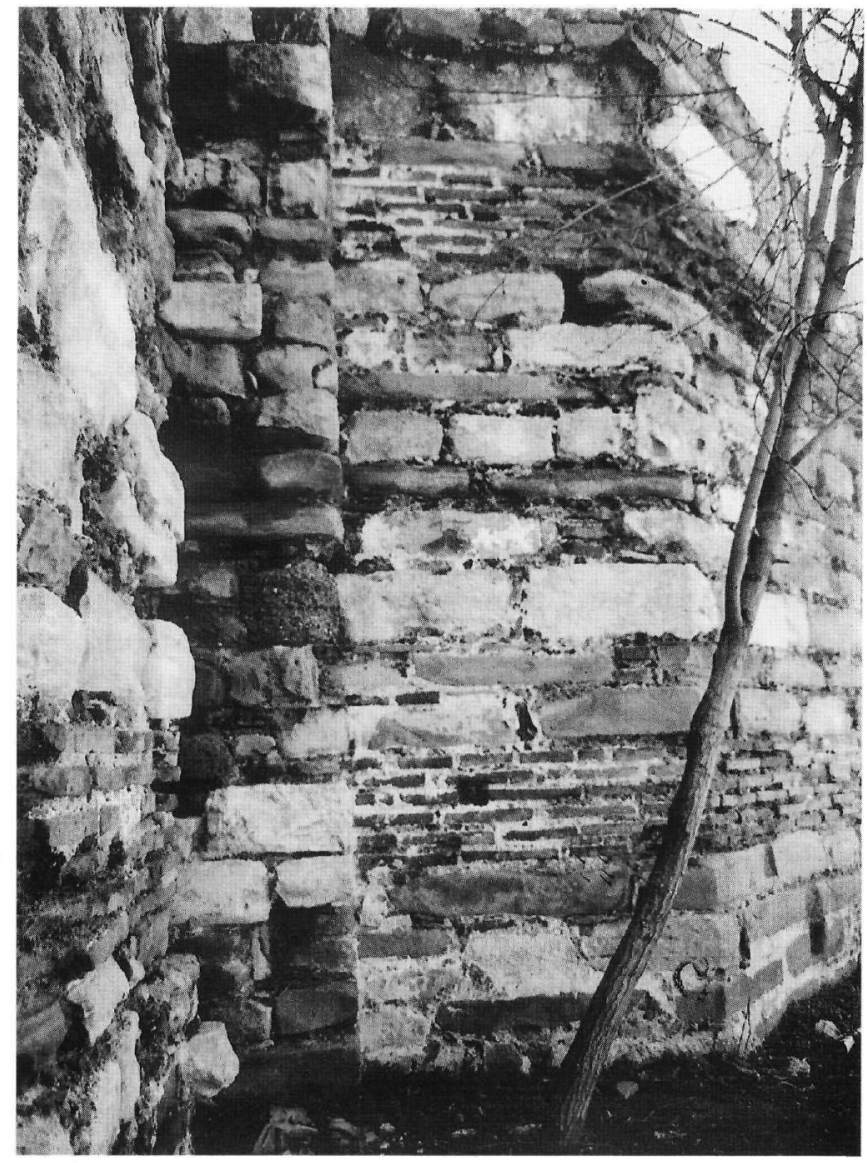

Fig. 10. The brick courses end at the corner where walls ' $e$ ' and ' $d$ ' of tower II meet.

water at wall 'i' may be observable especially during springtime probably owing to the cavity of the girders behind the surface of the wall. There are two different wall techniques employed at this wall, one being from the bottom to a height of 1.5 meter. The wall technique used at the bottom level of this wall repeats in walls ' $m$ ' and ' $n$ ' of Tower III (Fig. 10). The six brick course bands terminating at wall ' 1 ' meet at the
Üniversitesi yayımlanmamış doktora tezi, İstanbul 1984. According to the information gathered in this study; using $36-39 \mathrm{~cm}$ bricks, in Istanbul during the fifth century Sancaktar Mosque (Index no. 13), Hagia Euphemia Martirion (Index no. 14); in Istanbul city walls (Index nos 20), on Belgrade entranceway and Silivri entranceway (Index no. 22 and 23), in a structure close to Bodrum Mosque (Index no. 26), in Balabanaga Mosque (Index no. 27), in Chalkopreteia Church (Index no. 28), in a structure close to Chalkopreteia Church (Index no. 29), in Aspar Cistern (Index no. 33), Studios Monastery Church (Index no. 34); in Ayatekla Cistern in Silifke
(Index nos 36-37), in Mokios Cistern (Index no. 43); Istanbul Ayasofya (Hagia Sofia) Baptistery (Index no. 53), Ayasofya (Hagia Sofia) Treasury Building (Index no. 54) dating before 532; in Hormisdas Palace (Index no. 58) dating for 532 tarihli; Efes Double Church (Index no. 73) dated to seventh century. In addition, for brick material used in Byzantine structures in Istanbul see Y. Kahya, İstanbul Bizans Mimarisinde Kullanilan Tuglanin Fiziksel ve Mekanik Ozellikleri, ITU Fen Bilimleri Enstitüsü yayimlanmamış doktora tezi, Istanbul 1992; for sizes of the bricks see esp. 46-8. 
upper section of wall ' $\mathrm{j}$ ' of Tower III. It is apparent from the traces of the bricks that this course of bricks continues to the upper section of wall ' $\mathrm{k}$ '.

With the help of this building element, it was possible to trace the bands of brick at wall ' $d$ ' up to wall 'c' of Tower I to the north and wall ' $\mathrm{k}$ ' of Tower III to the south when following the plan obtained at the west wall. This building element which was interrupted by the application of varying building materials and techniques, points to an earlier period of building (Fig. 8). Apparently, the sections of walls where the relevant techniques differ represent renovations performed in later periods. The sizes of the bricks used in wall 'd' support the assumption that first building period is the wall sections shown in Drawing I built with stones and bricks using alternating technique. With their large sizes, the bricks conform to the characteristics of bricks used in the early Byzantine period ${ }^{23}$. The dimension of bricks used in Byzantine structures in Istanbul, varying between $30-40 \times 3-5.5 \mathrm{~cm}$, were determined as being larger and thicker than those of similar bricks of the Roman and Ottoman Empires despite having the same shape ${ }^{24}$. Bricks of the same dimension were used at walls ' $c$ ', ' $\mathrm{f}$ ', ' $\mathrm{g}$ ', ' $\mathrm{j}$ ' and ' $\mathrm{k}$ ' where bands of brick in these walls continued. However, we observe bricks in sizes 24 to $25.5 \times 12 \times 3.5-4 \mathrm{~cm}$ at the corners where walls ' $b$ ' and ' $c$ ' of Tower I meet, thereby indicating that renovation was performed in a different period.

Among the bands of bricks representing the early period in wall 'd', it is seen, especially at the southern edge of wall 'd' that connects to the pentagonal tower, that architectural plastic materials of the Byzantine time are used as spolia

\footnotetext{
${ }^{23}$ The edge lengths of bricks changes between $37-39 \mathrm{~cm}$ in this period. The shortest ones are $35 \mathrm{~cm}$ and the longest ones are $40 \mathrm{~cm}$. It is determined that the bricks are $33-36 \mathrm{~cm}$ in structures in Istanbul during the middle Byzantine period. The Hippodrome, the oldest structure in Istanbul, has square bricks with sizes ranging between $30-31 \mathrm{~cm}$. These bricks may be considered as a continuity of Roman traditions and it is suggested that the bricks in such sizes are not found in any other structures except the ones from the late Byzantine period. See Kahya, op.cit. In addition for another castles this region see, A. Caylak Turker, "Atik Hisar (Gavur Hisar) Castle", V. Ortaçag ve Turk Donemi Kazi ve Araştirmalari Sempozyumu, Hacettepe Üniversitesi Edebiyat Fakültesi Sanat Tarihi Bölümü, Ankara 2001, 193-206; W. Müller-Weiner, "Pegai - Karabiga, eine mittelalterliche Stadt", Jale Inan Armagani, Istanbul 1989, 170-76.

${ }^{24}$ Kahya, op.cit., 46-48; Tunay, op.cit.

${ }^{25}$ Y. Otüken, Nordwestlichen Kleinasien, IstMitt, Beiheft 41, Tübingen 1996, pl. 3.3; E. Parman, Ortaçagda Bizans Doneminde Frigya (Phrygia) ve Bolge Muzelerindeki Bizans Taş Eserleri, Eskișehir, Anadolu Universitesi Yayınlari 2002, figs 57, 52 and 53. U. Peschlow, A. PeschlowBindokat, M. Wörrle, "Die Sammlung Turan Beler in Kumbaba bei Şile (II). Antike und byzantinische Denkmäler von der bithynischen
}

(Fig. 9). These materials, which may belong to a renovation of the walls, are pieces of temple steps whose similar structures are encountered in the early Byzantine period ${ }^{25}$. The spolia materials, possibly belonging to the second building period of the wall, are used in walls ' $\mathrm{f}$ ' and ' $\mathrm{g}$ ' of Tower II. One of these pieces is an example of a flat step frequently encountered in the early Byzantine period ${ }^{26}$. These data indicate renovations of defence walls during the late Byzantine or Ottoman periods. Besides the spolia materials at Tower II, the large stones placed among the first and second brick courses of wall ' $\mathrm{d}$ ', that break the alignment and order of the stones, may be considered as materials of the wall from a second building period. Similar stones are used in the 'i' section of the west wall and walls ' $\mathrm{m}$ ' and ' $\mathrm{n}$ ' of Tower III. These are porous stones densely comprised of seashells. It is seen that such stone is also to be found at the Hallaci Mansur Tomb and other civil structures from the Ottoman period. At this stage in the study, it was thought that these stones were likely of local origin and were similar to the rocks having dense seashell content at the Fener region. As a result of further examinations performed in the locality, we detected a stone quarry thus showing that the stones had been extracted from rocks through cutting ${ }^{27}$. Further data pertaining to the second building period of the wall is the christogram pattern created using brick materials. The pattern found at wall 'e' of Tower II is frequently seen to be implemented in late Byzantine structures. The pattern squeezed within the wall texture is of great significance as it indicates a renovation during late Byzantine or early Ottoman period ${ }^{28}$.

\footnotetext{
Schwarzmeerküste", IstMitt 52 (2002), 429-522, esp. 500, 27.

${ }^{26}$ For types and usage of these steps and for other similar examples, see Z. Mercangoz, "Byzantine Buildings in Kusadasi Park", in Otuken, op.cit., pls 21, 22 and 23.1-2; for a similar sample at Seyitgazi Museum, see Parman, op.cit., pl. 134 fig. 184.

${ }^{27}$ In addition, there is another stone quarry at a rocky area of former Gallipoli-Bolayir seaway in the environs of Gallipoli; for further information relating to the inactive stone quarry, see Sakinç and Yaltirak, op.cit. (n. 7), 51 .

${ }^{28}$ For information about adornment created using brick materials used in late period structures, see Z. Mercangöz, Bati Anadolu'da Geç Dönem Bizans Mimarisi: Laskarisler Dönemi Mimarisi, H.U. Sosyal Bilimler Enstitüsü, Sanat Tarihi Anabilim Dalı, Yayimlanmamiş doktora tezi, İzmir 1985, 154-5 Evaluation of Building Catalogue; see. Y. Otuken, "Karacbey İlçesindeki Tophisar Köyünün Ortaçagdaki Önemi ve Tarihi Eserleri, Ege Universitesi Arkeoloji-Sanat Tarihi Dergisi IV (1988), 89-99, esp. 96; Y. Otuken, "İstanbul Son Devir Bizans Mimarisinde Cephe Süslemeleri”, Vakiflar Dergisi 12 (1978), 213-33; Otuken, "Bizans Duvar Tekniginde Tektonik ve Estetik Çözümler" Vakiflar Dergisi 21 (1990), 395-410.
} 
The third building period we observed at the west wall is characterized by the usage of small stones. The wall structure built using small stones to the north of wall 'd' appears again in the middle and southern part of the third band of bricks at the same wall. The material and technique relating to the third building period may be traced at section 'i' of the west wall particularly above the 1.5 meter level. Stones having similar characteristics were also observed at walls ' $a$ ' and 'b' of Tower I. Tournefort informs that the Castle was a ruin at the end of the seventeenth century ${ }^{29}$. The engravings produced in the eighteenth century and in the second half of nineteenth century again show the Castle as being partly ruined $^{30}$. The renovations representing the third building period of the west wall may possibly be dated as having been performed at the end of the nineteenth century or early twentieth century. The hill may well have been modified during the time of construction of the Government office. The reason this west wall has survived to the present day while the other walls had totally collapsed may be owing to the fact that it was serving as support for the garden backfill of the government office. Cemsut blocks and cement mortar from the twentieth century were traced in the west wall - further evidence that the wall has survived thanks to renovations performed. It is understood that such renovations were mostly performed at wall ' $i$ '. The reason behind being able to arrive at the plan of the Castle even though all walls had collapsed, with the exception of the west wall, was because the garden walls surrounding the government office had used the mortar stones of the Castle walls as footings.

At the end of this study, performed in three stages in line with the objectives we had determined, it may be understood that Gallipoli Castle has a square-like rectangular plan. It is seen that this plan possesses the traces of building patterns representing the periods from early Byzantine to late Byzantine and Ottoman. The data collected during this study may well contribute towards further studies to be performed in Gallipoli and Gallipoli Castle. Another question that may be raised following this study is whether the square-like rectangular Castle had a second defence line? The answer to this question could be clarified through comprehensive work supported with an archeo-geophysics excavation work.

\footnotetext{
${ }^{29}$ Tournefort, op.cit. (n. 4), 2005; for description of the castle in travel book, see footnote 2 .

${ }^{30}$ For written and descriptive data on the Castle, see footnotes 4 and 5.
}

\section{AYŞE C. TURKER}

Assistant Associate Prof. Dr. Ayse C. Turker, Canakkale Onsekiz Mart University, Faculty of Science and Letters, Department of History of Art. 


\section{Ayșe C. Turker}

\section{TO KA $\Sigma$ TPO TH $\Sigma$ KA $\Lambda$ IПО $\Lambda \mathrm{H} \Sigma$ KATA TH BYZANTINH EПOXH}

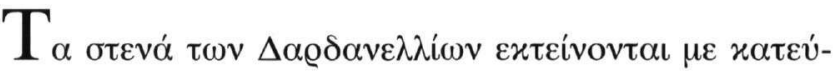

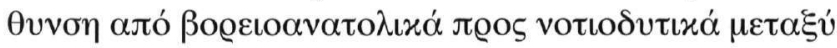

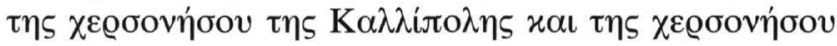



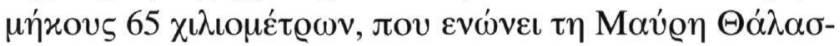

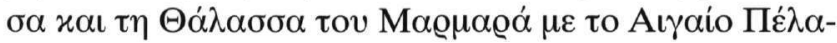



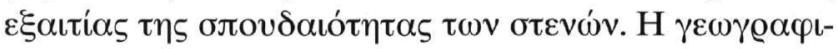

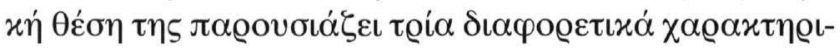

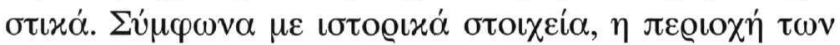

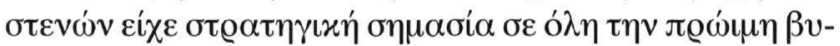

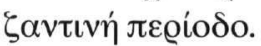

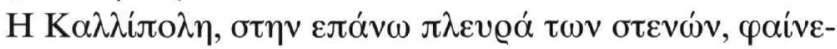

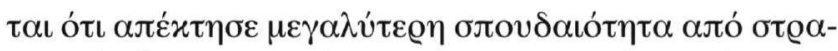

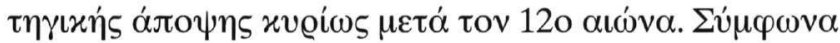

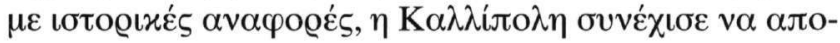

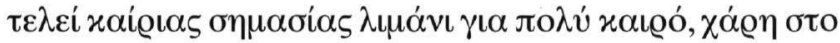

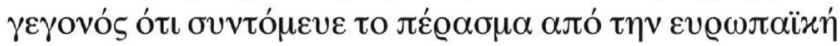

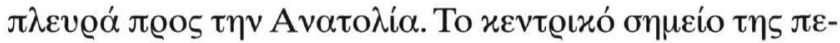

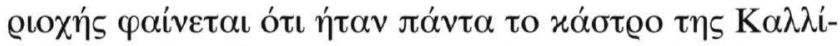



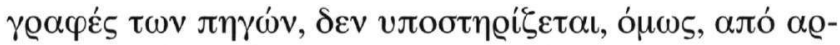

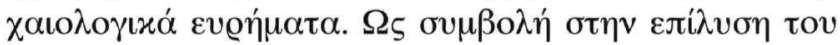

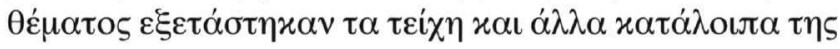

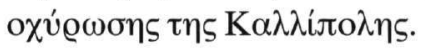

